\title{
PROTOTYPE SISTEM INFORMASI PERHITUNGAN NILAI POIN PELANGGARAN TATA TERTIB PADA SMK YUPPENTEK 1 TANGERANG
}

\author{
Himawan ${ }^{1}$ \\ Dede Cahyadi ${ }^{2}$ \\ Munawati $^{3}$ \\ Dosen STMIK Raharja Jurusan Teknik Informatika ${ }^{1}$, Dosen AMIK Raharja Informatika Jurusan \\ Komputerisasi Akuntansi ${ }^{2}$, Alumni STMIK Raharja Jurusan Sistem Informasi ${ }^{3}$ \\ Email : himawan@raharja.info,dede.cahyadi@raharja.info,munawati@raharja.info
}

Diterima : 8 Juli 2016/Disetujui : 21 Juli 2016

\begin{abstract}
creating a school atmosphere orderly and discipline is very important. Therefore is necessary to a regulation rules which would regulate the behavior patterns of students in the school. But with a growing pattern of student behavior, violation of school rules are common, especially in SMK Yuppentek 1 Tangerang. As a teacher in charge of providing services and counseling to students, it is the responsibility of counseling teachers to provide guidance to students with problems. Not many schools are aware of the importance of the use of information and communication technologies so that the process of recording and calculating the value of point offense, coaching up sanctions against students who violate the order was carried out with conventional systems. This resulted in the BK teachers takes a long time to handle students who have problems of having to create some bookkeeping records violation and fill the violation book manually so that the handling results are often invalid. In addition, delivery of information about good and bad behavior of students in the school to parents or guardians of students experiencing difficulties. In order to help the BK teacher performance, it needs to be made a system to calculate the point value rules violation at SMK YUPPENTEK 1 Tangerang. By using the methodology of research in the form of a SWOT analysis, it is expected that the system can simplify and accelerate the process of calculation of point offense, coaching until the sanctions to students who violate rules, and the delivery of information to parents or guardians of the student's behavior will be faster.In addition, principals can also find charts the level of discipline students based on grade level and department.
\end{abstract}

Keywords : violation points, sanctions violation, information system, SWOT

\begin{abstract}
ABSTRAKSI
Menciptakan suasana sekolah yang tertib dan disiplin sangatlah penting, oleh karena itu perlu adanya sebuah peraturan tata tertib yang akan mengatur pola tingkah laku siswa di sekolah. Namun seiring berkembangnya pola tingkah laku siswa, pelanggaran terhadap peraturan tata tertib sekolahpun sering terjadi khususnya di SMK Yuppentek 1 Tangerang. Sebagai guru yang bertugas memberikan pelayanan dan bimbingan konseling kepada siswa, sudah menjadi tanggungjawab guru BK untuk memberikan pembinaan terhadap siswa-siswi yang bermasalah. Belum banyak sekolah yang menyadari pentingnya pemanfaatan teknologi informasi dan komunikasi sehingga proses pencatatan dan perhitungan nilai poin pelanggaran, pembinaan sampai pemberian sanksi terhadap siswa yang melanggar tata tertib masih dilakukan dengan sistem yang konvensional. Hal tersebut mengakibatkan guru BK membutuhkan waktu yang cukup lama dalam hal penanganan siswa yang bermasalah, hal ini terjadi karena harus membuat beberapa arsip pembukuan pelanggaran dan mengisi buku pelanggaran tersebut secara manual sehingga hasil penanganannya pun sering tidak valid. Selain itu, penyampaian informasi mengenai baik buruknya perilaku siswa di sekolah kepada orangtua atau wali murid mengalami kesulitan. Dalam rangka untuk membantu kinerja guru BK, maka perlu dibuatnya sebuah sistem untuk menghitung nilai poin pelanggaran tata tertib pada SMK Yuppentek 1 Tangerang. Dengan menggunakan metodologi penelitian berupa analisis SWOT, maka diharapkan sistem tersebut dapat mempermudah dan mempercepat proses perhitungan nilai poin pelanggaran,
\end{abstract}


pembinaan, sampai pemberian sanksi kepada siswa yang melanggar tata tertib, serta penyampaian informasi kepada orangtua atau wali murid mengenai perilaku siswa akan lebih cepat. Selain itu, kepala sekolah juga dapat mengetahui grafik tingkat kedisiplinan siswa berdasarkan tingkatan kelas dan jurusannya.

Kata kunci : poin pelanggaran, sanksi pelanggaran, sistem informasi, SWOT

\section{PENDAHULUAN}

Pendidikan mempunyai peranan yang sangat penting dalam kehidupan manusia. Semakin tinggi pendidikan seseorang maka akan semakin tinggi wawasan dan pengetahuannya. Sekolah merupakan salah satu lembaga pendidikan formal tempat dimana anak dapat menggali dan mengembangkan potensi yang ada pada dirinya. Dalam upaya mengoptimalkan pembentukan kepribadian peserta didik, maka sekolah perlu menanamkan tata tertib terhadap siswa. Keberadaan tata tertib sekolah berfungsi sebagai pedoman bagi siswa dalam berperilaku di lingkungan sekolah.

Seiring dengan berkembangnya pola perilaku siswa khususnya di SMK Yuppentek 1 Tangerang, maka tidak mengherankan jika sering dijumpai siswa yang melanggar aturan dan tata tertib sekolah. Pelanggaranpelanggaran yang biasa dijumpai di sekolah cukup beragam, diantaranya datang terlambat, membolos, merokok, berkelahi, serta masih banyak lagi pelanggaran-pelanggaran lainnya. Tentunya telah menjadi tugas guru khususnya guru bimbingan konseling (BK) untuk memberikan pembinaan dan sanksi bagi siswa yang bermasalah.

Perhitungan terhadap nilai poin pelanggaran siswa pada SMK Yuppentek 1 Tangerang masih menggunakan sistem konvensional dimana guru BK harus mencatat setiap pelanggaran siswa dalam sebuah buku besar dan mengitung nilai poin pelanggaran setiap siswa untuk diberikan sanksi sesuai tata tertib yang berlaku. Hal ini tentunya mengakibatkan sering terlambatnya proses penindaklanjutan terhadap siswa yang bermasalah.

Dalam rangka untuk membantu kinerja guru BK dalam menangani siswa bermasalah, maka penulis tertarik untuk merancang suatu sistem informasi perhitungan nilai poin pelanggaran tata tertib siswa pada SMK Yuppentek 1 Tangerang.

\section{PERMASALAHAN}

Penggunaan sistem yang masih konvensional dalam melakukan perhitungan nilai poin pelanggaran tata tertib yang dilakukan oleh siswa di sekolah memang cukup merepotkan guru bimbingan konseling (BK). Hampir setiap hari guru BK harus menangani siswa yang melakukan berbagai jenis pelanggaran mulai dari pelanggaran dengan kategori kecil, sedang, sampai kepada pelanggaran besar yang harus ditangani secara cepat dan diberikan sanksi sesuai dengan pelanggaran yang dilakukan.

Setiap pelanggaran tata tertib di sekolah memiliki poin-poin tersendiri sesuai dengan jenis pelanggarannya. Untuk memberikan pembinaan sanksi kepada siswa yang melanggar maka guru BK harus mencatat terlebih dahulu setiap pelanggaran siswa ke dalam sebuah buku besar kemudian menghitung nilai poin pelanggaran setiap siswa. Setelah nilai poin pelanggaran diketahui, maka guru BK baru dapat memberikan tindakan kepada siswa yang melanggar dan memberikan sanksi sesuai dengan nilai poin pelanggarannya mulai dari diberikan peringatan oleh wali kelas dan guru Bimbingan Konseling (BK), membuat surat perjanjian yang dibubuhi tanda tangan diatas materai sampai pada tingkat yang paling tinggi dengan bobot atau nilai poin pelanggaranpaling besar yaitu dikembalikan kepada orang tua atau wali.

Tentunya hal tersebut membutuhkan waktu yang lama karena harus membuat beberapa arsip pembukuan pelanggaran dan mengisi buku pelanggaran tersebut secara manual sehingga hasil penanganannya pun sering tidak valid. Selain itu penyampaian informasi kepada orangtua atau wali murid mengenai baik buruk perilaku siswa mengalami kesulitan. Untuk mengatasi permasalahan tersebut, maka perlu dibuat sebuah sistem informasi untuk menghitung nilai poin pelanggaran siswa sehingga pekerjaan guru BK dalam menangani, membina, dan memberikan sanksi kepada 
siswa yang melanggar tata tertib akan lebih cepat dan tepat sasaran.

Dari penjelasan diatas dapat dirumuskan beberapa permasalahan yaitu :

1. Bagaimana sistem pemberian sanksi bagi siswa yang melanggar tata tertib yang sedang berjalan pada SMK Yuppentek 1 Tangerang ?

2. Bagaimana merancang sistem informasi perhitungan nilai poin pelanggaran tata tertib berbasis web pada SMK Yuppentek 1 Tangerang?

\section{LITERATURE REVIEW}

Banyak penelitian sebelumnya mengenai sistem informasi perhitungan nilai poin perlanggaran tata tertib. Dalam upaya mengembangkan dan menyempurnakan proses perhitungan nilai poin pelanggaran tata tertib pada SMK Yuppentek 1 Tangerang ini perlu dilakukan studi pustaka sebagai salah satu dari penerapan metode penelitian yang akan dilakukan.

Beberapa Literature review tersebut adalah sebagai berikut :

1. Penelitian yang dilakukan oleh Patmi Kasih dan Yuni Lestari pada tahun 2015 dari Universitas Nusantara PGRI Kediri yang berjudul "Aplikasi Penghitung Point Pelanggaran Siswa Sebagai Sistem Pendukung Keputusan Bagi Badan Konseling Sekolah Dengan Simple Additive Weighting (Studi Kasus: SMK N 1 Tanah Grogot-Kaltim). Penelitian ini membahas mengenai Aplikasi penghitung poin kesalahan yang dirancang dengan menggunakanberbasis web dengan harapan dapat mempermudah hak akses yang dituju. Aplikasi ini dirancang sebagai sistem pendukung keputusan bagi guru dan badan bimbingan konseling sekolah dengan tujuan untuk mempermudah Guru Bimbingan Konseling dalam penanganan siswa bermasalah guna menentukan poin kesalahan dan memperoleh data-data yang valid dengan menerapkan FuzzyMulti Attribute Decision Making (FMADM), dan metode Simple Additive Weighting (SAW). [1]

2. Penelitian yang dilakukan oleh Ellen Ershinta Putri dan Azis Ahmadi pada tahun 2015 dari Universitas Yudharta
Pasuruan yang berjudul "Perancangan Sistem Informasi Poin Pelanggaran Dan Prestasi Siswa Berbasis Sms Gateway Pada Sekolah Menengah Kejuruan Negeri 3 Pacitan". Penelitian ini menjelaskan bahwa sistem pencatatan poin pelanggaran siswa masih menggunakan sistem yang konvensional sehingga membutuhkan waktu dan ketelitian dan mengakibatkan tindakan pelanggaran yang di ambil sering terlambat. Untuk mengatasi berbagai permasalahan tersebut maka dirancang sebuah sistem informasi poin pelanggaran dan prestasi siswa berbasis sms gateway pada Sekolah Menengah Kejuruan Negeri 3 Pacitan yang diharapkan dapat mempermudah orang tua mengetahui pelanggaranpelanggaran anaknya secara cepat sehingga dapat memperkecil tingkat kenakalan siswa disekolah. [2]

3. Penelitian yang dilakukan oleh Fandi Setyo Prambudi, Mochammad Arifin, Vivine Nurcahyawati pada tahun 2012 dari SekolahTinggi Manajemen Informatika dan Teknik Komputer Surabaya yang berjudul "Sistem Informasi Monitoring Siswa Bermasalah Berbasis Web dan SMS Gateway (Studi Kasus : SMA Negeri 2 Trenggalek)". Penelitian ini dilatarbelakangi oleh kesulitan yang dihadapi oleh guru BK dalam menangani masalah yang ada karena tugas guru BK tidak hanya memberikan konseling terhadap siswa tetapi juga mengajar dan tugas-tugas lainnya. Pihak BK membutuhkan alat bantu untuk meringankan tugas guru BK yang awalnya dilakukan secara manual yaitu dengan mencatat seluruh kejadian atau masalah siswa kedalam buku dan melakukan perhitungan secara manual. Metode yang digunakan dalam penelitian ini yaitu metode Certainty Factor (CF). Teknologi yang digunakan berupa teknologi berbasis SMS gateway yang dimanfaatkan sebagai media layanan kepada orang tua dalam memantau perkembangan anaknya di sekolah. [3]

4. Penelitian yang dilakukan oleh Dwianto Nova Nugroho pada tahun 2014 dari Universitas Muria Kudus yang berjudul "Sistem Informasi Perhitungan Point Pelanggaran dan Pemberian Sanksi Pada Siswa SMK PGRI 1 Mejobo Kudus 
Berbasis Web dan SMS Gateway". Penelitian ini bertujuan untuk untuk merancang dan membangun suatu perhitungan poin pelanggaran dan pemberian sanksi pada siswa SMK PGRI 1 Mejobo Kudus melalui sms guna memudahkan guru BK atau penanggungjawab dalam mengelola data siswa yang melakukan pelanggaran. Konsep yang diterapkan dalam tahap perancangan sistem tersebut adalah dengan menggunakan metode Rekayasa perangkat lunak. [4]

5. Penelitian yang dilakukan oleh Apriyani pada tahun 2015 dari Universitas Negeri Yogyakarta yang berjudul "Pengembangan Dan Analisis Kualitas Sistem Pengelolaan Poin Pelanggaran Tata Tertib Siswa Berbasis Web Di SMK Muhammadiyah 1 Bantul". Penelitian ini termasuk kedalam jenis Research and Development (R\&D), sistem dikembangkan dengan model pengembangan Waterfall dan analisis kualitas sistem menggunakan beberapa instrumen penelitian sesuai dengan standar ISO 9126. Tujuan dari penelitian ini yaitu untuk mengembangkan sistem pengelolaan poin pelanggaran tata tertib siswa berbasis web yang sesuai dengan kebutuhan di SMK Muhammadiyah 1 Bantul dan mengetahui kualitas sistem pengelolaan poin pelanggaran tata tertib siswa berbasis web di SMK Muhammadiyah 1 Bantul berdasarkan standar ISO 9126. [5]

6. Rifqia Sandra Nastiti Universitas Negeri Yogyakarta 2015 yang berjudul "Sistem Informasi Pelanggaran Siswa Berbasis Web Pada Sma Negeri 1 Bawang Banjarnegara". Penelitian ini dilatarbelakangi oleh pengelolaan data pelanggaran di SMA Negeri 1 Bawang masih dikelola secara konvensional. Datadata pelanggaran siswa masih disimpan dalam lembaran-lembaran kertas dan ditumpuk begitu saja sehingga dapat menyebabkan terjadinya kerusakan bahkan kehilangan data. Selain itu, orangtua atau wali siswa sulit memantau atau mengontrol anaknya karena kurang maksimalnya ketersampaian informasi. Penelitian ini bertujuan untuk mengembangkan dan menganalisis kualitas sistem informasi pelanggaran siswa pada SMA N 1 Bawang Banjarnegara. Metode yang digunakan adalah Research \& Development (R\&D) dengan metode pengembangan sistem waterfall. [6]

\section{PEMECAHAN MASALAH}

Setelah meneliti dan mengamati beberapa permasalahan yang terjadi di dalam sistem perhitungan poin pelanggaran tata tertib di SMK Yuppentek 1 Tangerang, penulis memberikan beberapa alternatif pemecahan masalahan yang dihadapi sistem yang berjalan yaitu :

1. Membuat sebuah sistem yang dapat mempercepat dan juga mempermudah proses perhitungan poin pelanggaran siswa sehingga dapat mempermudah kinerja guru BK dan juga para wali kelas dalam menangani siswa-siswa bermasalah.

2. Sistem yang dirancang dapat menjadi fasilitas atau media informasi bagi orangtua atau wali murid dalam memantau secara langsung tingkat kedisiplinan siswa di sekolah.

3. Sistem tersebut dapat memberikan laporan yang akurat kepada sekolah mengenai tingkat kedisiplinan siswa di sekolah berdasarkan tingkatan kelas dan masing-masing jurusan.

\section{Flowchart Sistem Usulan}

Berikut gambar flowchart sistem yang akan diusulkan pada SMK Yuppentek 1 Tangerang :

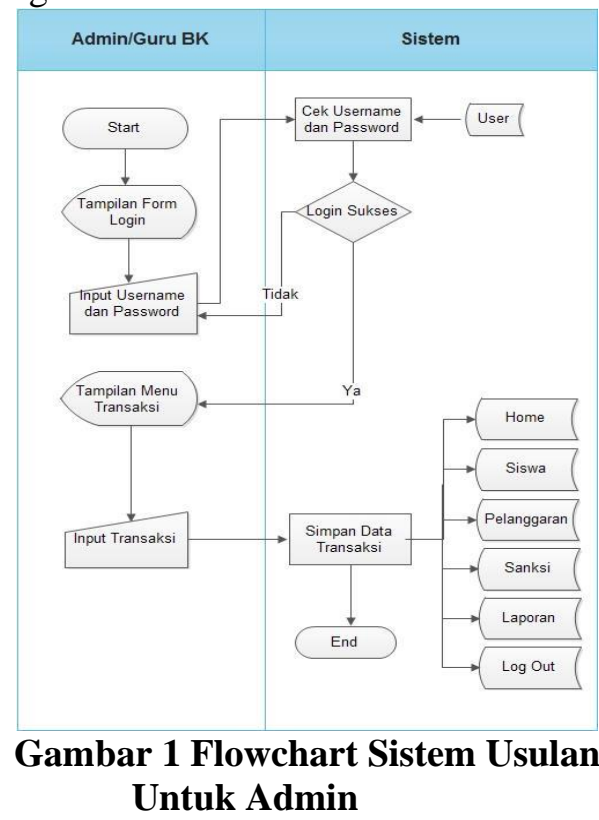


Untuk masuk ke sistem, maka admin atau guru BK harus melakukan login terlebih dahulu. Setelah login berhasil, maka pengguna akan masuk ke sistem dan akan muncul menu sesuai dengan hak akses pengguna. Menumenu yang terdapat pada sistem yang diusulkan yaitu: Home, Siswa, Pelanggaran, Sanksi, Laporan, dan Log Out.

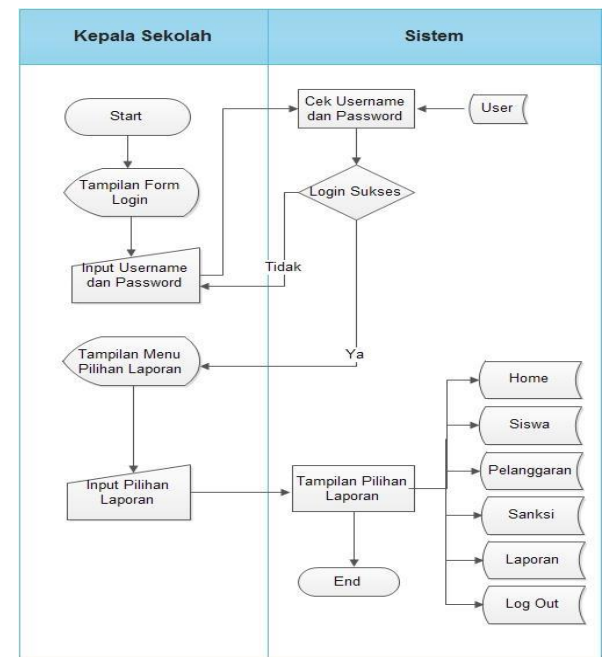

\section{Gambar 2 Flowchart Sistem Usulan Untuk Kepala Sekolah}

Untuk masuk ke sistem, kepala sekolah harus melakukan login terlebih dahulu. Setelah login berhasil, maka kepala sekolah memilih menu Laporan untuk melihat grafik tingkat kedisiplinan siswa yang telah dikelompokkan berdasarkan kelas, jurusan, maupun tingkatnya.

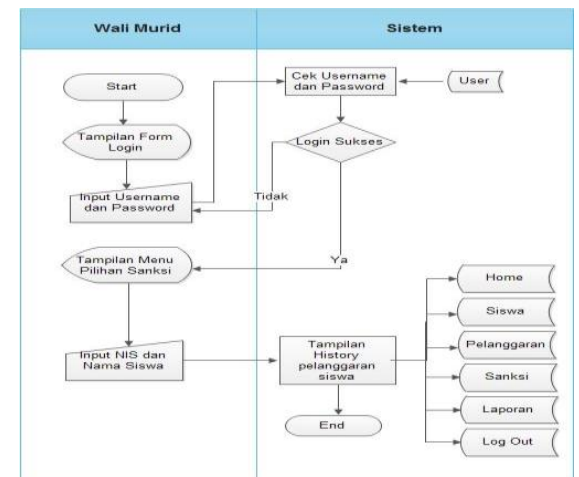

\section{Gambar 3 Flowchart Sistem Usulan Untuk Wali Murid}

Untuk bisa melihat jumlah poin pelanggaran yang dilakukan oleh siswa dan memantau kedisiplinan siswa disekolah maka wali murid harus melakukan proses login terlebih dahulu. Dengan adanya sistem ini, maka orangtua atau wali murid dapat memantau secara langsung kedisiplinan siswa di sekolah.

\section{IMPLEMENTASI}

\section{Prototype Form Login}

Untuk masuk ke dalam sistem, hal pertama yang harus dilakukan oleh user yaitu mengisi nama dan password pada form login. Berikut adalah tampilan dari form login :

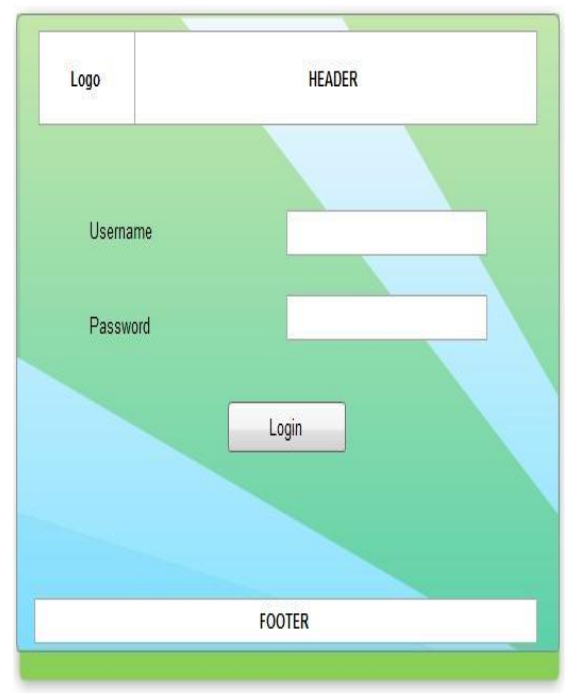

Gambar 4 Prototype Form Login

\section{Prototype Tampilan Halaman Home}

Pada halaman Home terdapat visi, misi, dan tujuan dari SMK Yuppentek 1 Tangerang. Berikut adalah tampilan dari halaman Home :

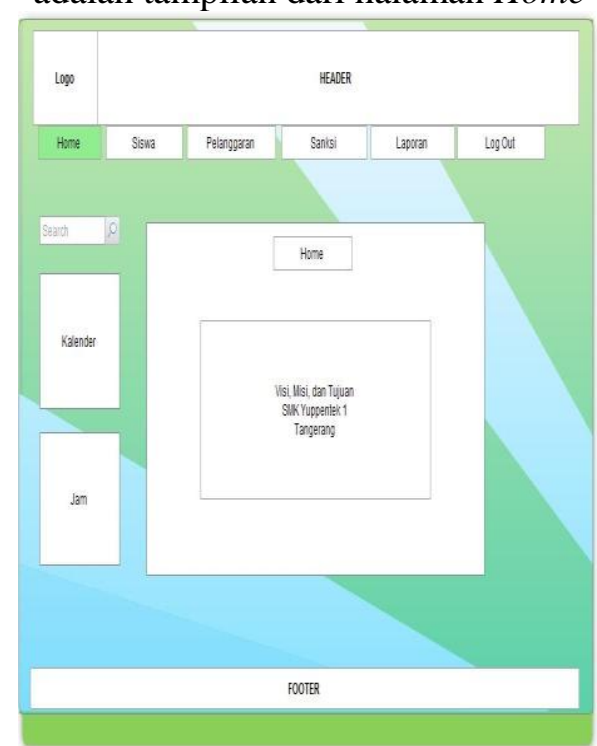

Gambar 5 Prototype Form Halaman Home 


\section{Prototype Tampilan Halaman Siswa} Halaman siswa berisi Form Data Siswa yang digunakan untuk mengelola data siswa agar mudah dalam pendistribusian informasinya. Jika admin ingin melakukan update data siswa maka dengan memilih data siswa yang akan diganti, menekan tombol edit, mengisikan data dan menekan tombol update. Berikut adalah tampilan halaman siswa :

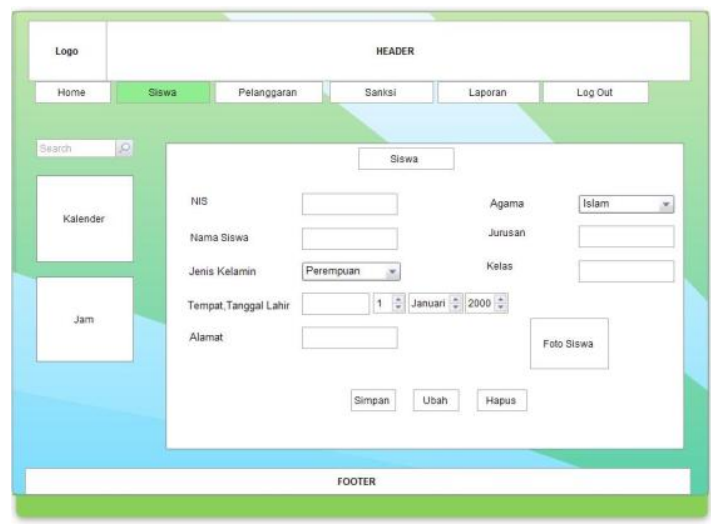

\section{Gambar 6 Prototype Form Halaman} Siswa

\section{Prototype Halaman Pelanggaran}

Langkah selanjutnya adalah pergi ke form Input Pelanggaran pada halaman pelanggaran untuk memasukan data pelanggaran yang terjadi pada siswa SMK Yuppentek 1 Tangerang. Berkut adalah tampilan dari form Input Pelanggaran.

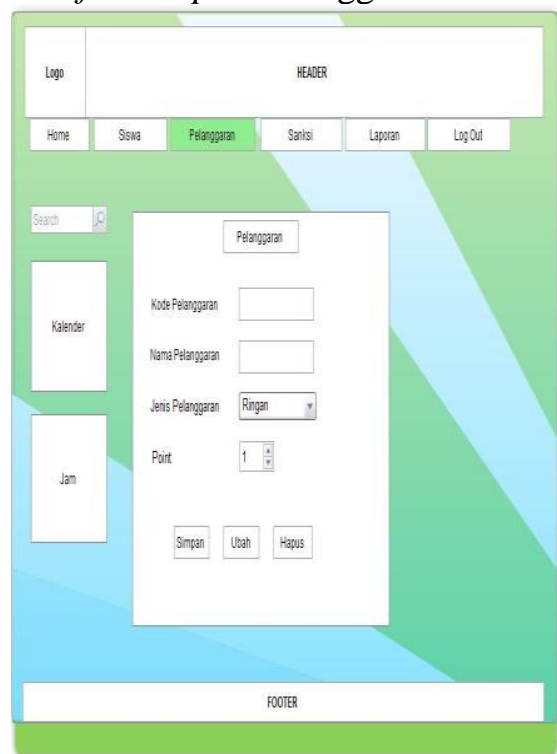

Gambar 7 Prototype Form Halaman Pelanggaran
5. Prototype Tampilan Halaman Sanksi

Halaman Sanksi dilengkapi dengan tabel detail pelanggaran siswa yang berupa NIS, nama siswa, kelas, jurusan, kode pelanggaran, jenis Pelanggaran, tanggal pelanggran, poin, jumlah poin, sanksi, wali kelas, status sanksi, dan dilengkapi juga dengan form pencarian.[7] Berikut adalah tampilan halaman sanksi:

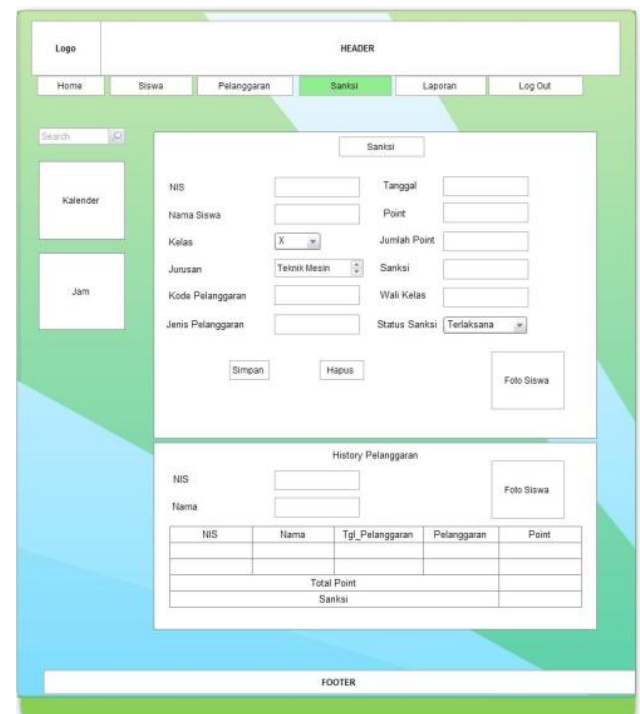

Gambar 8 Prototype Form Halaman Sanksi

6. Prototype Tampilan Halaman Laporan

Halaman laporan berisi laporan kedisiplinan siswa yang telah dikelompokkan berdasarkan kelas, jurusan, dan tingkat. Laporan tersebut disajikan dalam bentuk diagram lingkaran dan dapat diakses oleh kepala sekolah. Berikut adalah tampilan halama laporan : 


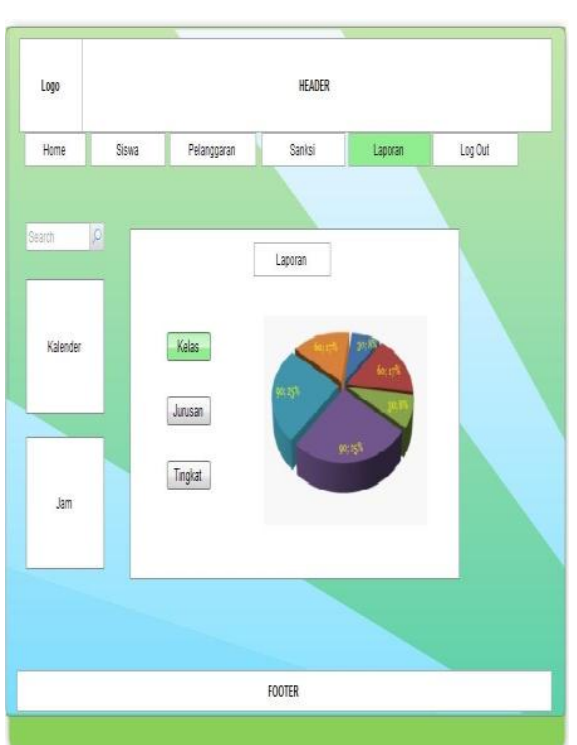

\section{Gambar 9 Prototype Form Menu Laporan}

\section{Pengujian Black Box Testing}

Metode pengujian black-box berusaha untuk menemukan kesalahan dalam beberapa kategori, diantaranya: fungsi-fungsi yang salah atau hilang, kesalahan interface, kesalahan dalam struktur data atau akses database eksternal, kesalahan performa, kesalahan inisialisasi dan terminasi.[8]

Tabel 1 Pengujian Black Box Testing

\begin{tabular}{|c|c|c|c|}
\hline No. & $\begin{array}{c}\mathrm{Na} \\
\mathrm{ma} \\
\text { For } \\
\mathrm{m}\end{array}$ & $\begin{array}{c}\text { Kondisi } \\
\text { Pengujian }\end{array}$ & Hasil Pengujian \\
\hline \multirow[t]{2}{*}{1} & $\begin{array}{l}\text { Lo } \\
\text { gin }\end{array}$ & $\begin{array}{l}\text { Username } \\
\text { dan } \\
\text { Password } \\
\text { tidak dii } \\
\text { si ke } \\
\text { mudian } \\
\text { menekan } \\
\text { tombol } \\
\text { login }\end{array}$ & 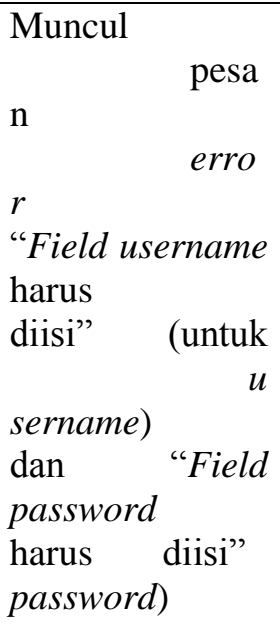 \\
\hline & & $\begin{array}{l}\text { Username } \\
\text { dan } \\
\text { Password } \\
\text { tidak benar } \\
\text { atau tidak }\end{array}$ & $\begin{array}{ll}\text { Muncul } & \\
\mathrm{n} & \text { pesa } \\
r & \text { erro } \\
r & \end{array}$ \\
\hline
\end{tabular}

\begin{tabular}{|l|l|l|l|}
\hline & & $\begin{array}{l}\text { cocok } \\
\text { dengan data } \\
\text { user }\end{array}$ & $\begin{array}{l}\text { "Maaf, userna } \\
\text { me dan } \\
\text { atau }\end{array}$ \\
& & $\begin{array}{l}d \text { anda } \\
\text { salah" }\end{array}$ \\
\hline 2 & $\begin{array}{l}\text { His } \\
\text { tor } \\
\text { y } \\
\text { Pel } \\
\text { ang } \\
\text { gar } \\
\text { an }\end{array}$ & $\begin{array}{l}\text { Total Poin } \\
\text { Pelanggara } \\
\text { n 25 }\end{array}$ & $\begin{array}{l}\text { Muncul pesan } \\
\text { "Siswa sudah } \\
\text { layak diberikan } \\
\text { peringatan" }\end{array}$ \\
\hline & $\begin{array}{l}\text { Total Poin } \\
\text { Pelanggara } \\
\text { n 50 }\end{array}$ & $\begin{array}{l}\text { Muncul pesan } \\
\text { "Siswa sudah } \\
\text { layak diberikan } \\
\text { pembinaan" }\end{array}$ \\
\hline & $\begin{array}{l}\text { Total Poin } \\
\text { Pelanggara } \\
\text { n 75 }\end{array}$ & $\begin{array}{l}\text { Muncul pesan } \\
\text { "Siswa sudah } \\
\text { layak diberikan } \\
\text { pembinaan dan } \\
\text { sanksi" }\end{array}$ \\
\hline & $\begin{array}{l}\text { Total Poin } \\
\text { Pelanggara } \\
\text { n 100 }\end{array}$ & $\begin{array}{l}\text { Muncul pesan } \\
\text { "Siswa } \\
\text { dikembalikan } \\
\text { kepada } \\
\text { orangtua" }\end{array}$ \\
\hline
\end{tabular}

\section{KESIMPULAN}

Berdasarkan hasil analisa dari penelitian yang telah dilakukan maka dapat disimpulkan bahwa sistem informasi perhitungan nilai poin pelanggaran pada SMK Yuppentek 1 Tangerang sangat dibutuhkan untuk membantu kinerja guru BK dalam menangani siswa-siswa yang melakukan pelanggaran dan memberikan sanksi sesuai dengan jumlah poin pelanggaran yang telah dilakukan. Dengan adanya sistem informasi perhitungan poin pelanggaran ini dapat menjadi fasilitas atau media bagi orangtua atau wali murid dalam memantau perilaku dan kedisiplinan siswa di sekolah. Selain itu, sistem tersebut dapat memberikan laporan yang akurat kepada sekolah mengenai tingkat kedisiplinan siswa-siswa di sekolah.

\section{DAFTAR PUSTAKA}

[1] Kasih, patmi dan Yuni Lestari. 2015. "Aplikasi Penghitung Point 
Pelanggaran Siswa Sebagai Sistem Pendukung Keputusan Bagi Badan Konseling Sekolah Dengan Simple Additive Weighting (Studi Kasus: SMK N 1 Tanah Grogot-Kaltim)". Jurnal Nusantara of Engineering. Kediri. Universitas Nusantara PGRI Kediri. Vol. 2 No. 1.

[2] Putri, Ellen Ershinta dan Azis Ahmadi. 2015. "Perancangan Sistem Informasi Poin Pelanggaran Dan Prestasi Siswa Berbasis Sms Gateway Pada Sekolah Menengah Kejuruan Negeri 3 Pacitan". IJNS - Indonesian Journal on Networking and Security. Pasuruan . Universitas Yudharta Pasuruan. Vol. 4 No.1, Januari 2015.

[3] Prambudi , Fandi Setyo, Mochammad Arifin, Vivine Nurcahyawati. 2012 "Sistem Informasi Monitoring Siswa Bermasalah Berbasis Web dan SMS Gateway (Studi Kasus : SMA Negeri 2 Trenggalek)". Jurnal Sistem Informasi dan Komputerisasi Akuntansi (JSIKA). Surabaya. Sekolah Tinggi Manajemen Informatika dan Teknik Komputer Surabaya. Vol.1 No.2.

[4] Nugroho, Dwianto Nova. 2014 Sistem Informasi Perhitungan Point Pelanggaran dan Pemberian Sanksi Pada Siswa SMK PGRI 1 Mejobo Kudus Berbasis Web dan SMS Gateway". Laporan Skripsi. Universitas Muria Kudus.

[5] Apriyani. 2015 . "Pengembangan dan Analisis Kualitas Sistem Pengelolaan Poin Pelanggaran Tata Tertib Siswa Berbasis Web Di SMK Muhammadiyah 1 Bantul". Laporan Skripsi. Universitas Negeri Yogyakarta.

[6] Nastiti, Rifqia Sandra. 2015. "Sistem Informasi Pelanggaran Siswa Berbasis Web Pada SMA Negeri 1 Bawang Banjarnegara". Laporan Skripsi. Universitas Negeri Yogyakarta.

[7] Kurniawan, Risang. 2012. "Sistem Informasi Data Poin Pelanggaran Siswa Sma Muhammadiyah 2
Yogyakarta Berbasis Java". Laporan Skripsi. Sekolah Tinggi Manajemen Informatika Dan Komputer Amikom Yogyakarta.

[8] Purnomo, Eko Sigit dan Febriliyan Samop. 2013. "Pembuatan Sistem Informasi Rekonsiliasi Keuangan Negara Menggunakan PHP dan MySQL". Jurnal TEKNIK POMITS ISSN: 2337-3539 . Surabaya. Institut Teknologi Sepuluh Nopember (ITS). Vol 